\title{
Water Quality Mapping of Piped Water Supply in Malang City - Indonesia
}

\author{
Rona Rofida $^{1}$, Nurina Fitriani ${ }^{2}$, Desy Galuh Indarko ${ }^{2}$, Adhi Yuniarto ${ }^{1}$, Bowo \\ Djoko Marsono ${ }^{1}$, Eddy Setiadi Soedjono,"*
}

${ }^{1}$ Environmental Engineering Department, Institut Teknologi Sepuluh Nopember, 60111 Surabaya, INDONESIA

${ }^{2}$ Study Program of Environmental Engineering, Department of Biology, Universitas Airlangga, 60115 Surabaya, INDONESIA

${ }^{3}$ Water Supply Company (PDAM) Malang City, Malang, INDONESIA

*Corresponding Author

DOI: https://doi.org/10.30880/ijie.2019.11.01.026

Received 07 July 2018; Accepted 18 December 2018; Available online 15 May 2019

\begin{abstract}
PDAM Tirta Dharma of Malang City is probably the only water supply company (PDAM) in Indonesia which distributes drinking water to its customers at city wide. The PDAM is easily entitled to distribute drinking water as the raw water is originated from springs and groundwater with high quality of raw water supply. Raw water is simply chlorinated prior to distribution which then water must have residual chlorine of at least $0.2 \mathrm{mg} / \mathrm{L}$, no total coliform, and minimum pressure heads of 1 bar at any house connection of the customers. PDAM Malang has 85 district meter areas (DMA) which covers $85 \%$ of Malang City in 2018. This study is aimed to assess public water service in Malang City regarding residual chlorine, total coliform, and residual heads at selected house connections which the results are then plotted using open source software of ArcGIS 10.3. Out of 85 DMA, 58 areas were able to distribute drinking water in accordance with Indonesia Drinking Water Standard. Out of 85 selected sampling points for the three water services, $68 \%$ showed that the water quality complied with Indonesia Standard.
\end{abstract}

Keywords: District meter areas

\section{Introduction}

PDAM Tirta Dharma as the sole water supply company in Malang City is one of PDAMs in Indonesia which supplies drinking water to its customers. The PDAM has 159.765 house connections which covers $85 \%$ of the City with a total area of ca. $110 \mathrm{~km} 2$ and population of 856.410 [1]. Provision of drinking water was started in 2004 with non-revenue water (NRW) of $19.38 \%$ by August 2017. Based on Ministry of Public Works Regulation number 12/PRT/M/2013 then unaccounted for water must be less than $20 \%$.

Piped water supply service in Malang City is definitely for 24 hours with raw water supply from different springs and ground water which its water quality has complied with Indonesia Drinking Water Standard of Ministry of Health Regulation number 492/MENKES/PER/IV/2010. Having raw water supply from springs and ground water, then water is merely chlorinated before being distributed. Based on the regulation, the residual chlorine must be at least $0.2 \mathrm{mg} / \mathrm{L}$ with total coliform of zero. This is absolutely important as raw water quality is susceptible to septic tank seepage [2]. Service area of PDAM Malang is shown in Fig. 1. 


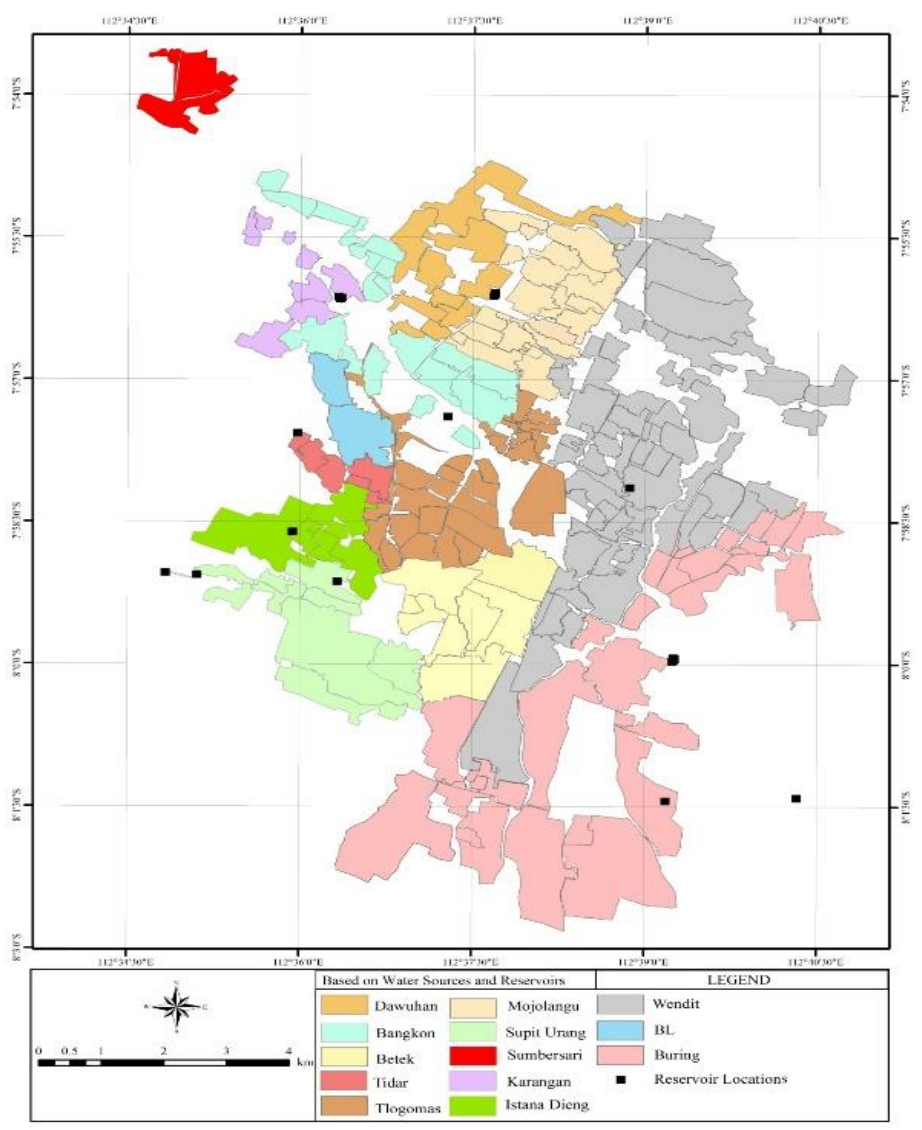

Fig. 1 - Service area PDAM Tirta Dharma of Malang City in 2016

Colours in the map is to show service area from each water sources and reservoirs; there are 13 sub-service areas. Having tap water which complies with drinking water standard was not acknowledged by many customers [3]. Many of the customers of PDAM were still doubt with its tap water quality which might not comply with the standards. Hence customers mapping was conducted and was coupled with water sampling to assess water quality compliance at the customers. Customers sampling included residual chlorine, total coliform, and pressure heads.

\section{Material and Method}

\subsection{Data Collection}

Water quality sampling was conducted to collect field data. The samplings included main tap water sampling and water pressure. Main tap was conducted from yard tap of individual houses to get water sample for chlorine residual and total coliform as well as getting water pressure from the tap. Residual chlorine was analyzed using colorimetric method [4] while total coliform was analyzed using APHA [5] as modified using instant petrifilm of 3M USA. Bacteria were spread upon petrifilm media and then was incubated for $2 \times 24$ hours to get the results under colony counter. Water sampling was conducted in February 2018 from08.00 to 11.00. Water quality results were compared with previous existing results of PDAM Tirta Dharma of Malang City.

\subsection{Number of Sampling Point}

Water sampling was conducted in February 2018 at 85 house connections. PDAM Malang has conducted its owned tap water sampling based on Ministry of Health Regulation number 492/MENKES/PER/IV/2010.

\subsection{Materials}

Materials for water sampling included: (i) sampling botols of $250 \mathrm{~mL}$, dried ice, and coolbox, (ii) materials for coliform test included: petrifilm media (3M,USA), incubator (Mamert, Germany), laminar flow cabinet (Esco, USA), oven (Heraeus, Germany), Autoclave (All American, USA), Electric sterilizer (Dragon 320, Taiwan), Colony counter (Funke Gerber, Germany), pipets, alcohol 70\%, NatriumTiosulfat $\left(\mathrm{Na}_{2} \mathrm{~S}_{2} \mathrm{O}_{3}\right) 10 \%$, and (iii) comparator (Lovibond, Germany), test tubes, and DPD 1 tablets (Diethyl PhenyleneDiamene) to test residual chlorine. 


\subsection{Data Analysis}

Water quality and water pressure results were plotted in map using an open source software of ArcGIS 10.3. The software required coordinate of sampling points including water quality parameter to be inputted. Three parameters as required in the Health Ministry Regulation wereresidual chlorine, total coliform, and residual head at selected house connections. Results were in the form of city map with the three parameters which could be easily plotted for further analysis for better water services of PDAM.

The three parameters were prepared in Microsoft Excel before being inputted into arcGIS as required by the software. Google map was used and adjusted to locate and superimpose sampling points of the three parameters. Results were in adjusted colors as shown later.

\section{Results and Discussion}

Although the distributed water has been chlorinated, some water deteriorations happen in the customer's due pipe leaks in the network and owned properties, pipe network maintenance which caused turbid water, and flooding. To cope with the problems, PDAM Malang relies on feedback from the customers as also mentioned by Masduqiet.al [6] that sustainable water depends on nine variables including type of raw water supply, investment, human resource, and community participation.

\subsection{Residual Chlorine}

Fig. 2 shows map of residual chlorine in the service area of PDAM Malang. Red dotted colors show sampling points which do not comply with Indonesian drinking water standards. Other colors are to show residual chlorine concentration although it is still $0.1 \mathrm{mg} / \mathrm{L}$ or more. Red dotted are mainly at Northern and Western part of Malang City as chlorine supply to the area is intermittent. Water distribution network from Banyuning Spring is even not chlorinated. Dosing pumpsatDawuhan do not function well yet, hence chlorination is not in proper operation. Chlorine concentration in pipe networks is affected by the distance of water travel; the more the travel distance is then the less the chlorine residual [7, $8,9,10]$. The distribution of red dotted colors are then not only due to unavailable of residual chlorine, but is also due to not the function of chlorine dosing pumps. Despite the situations on site, residual chlorine of $0.2 \mathrm{mg} / \mathrm{L}$ in all distribution system is required to deactivate microorganism in pipe networks [11]. Residual chlorine is much affected by type and number of microorganisms, $\mathrm{pH}$, temperature, contact time, etc.

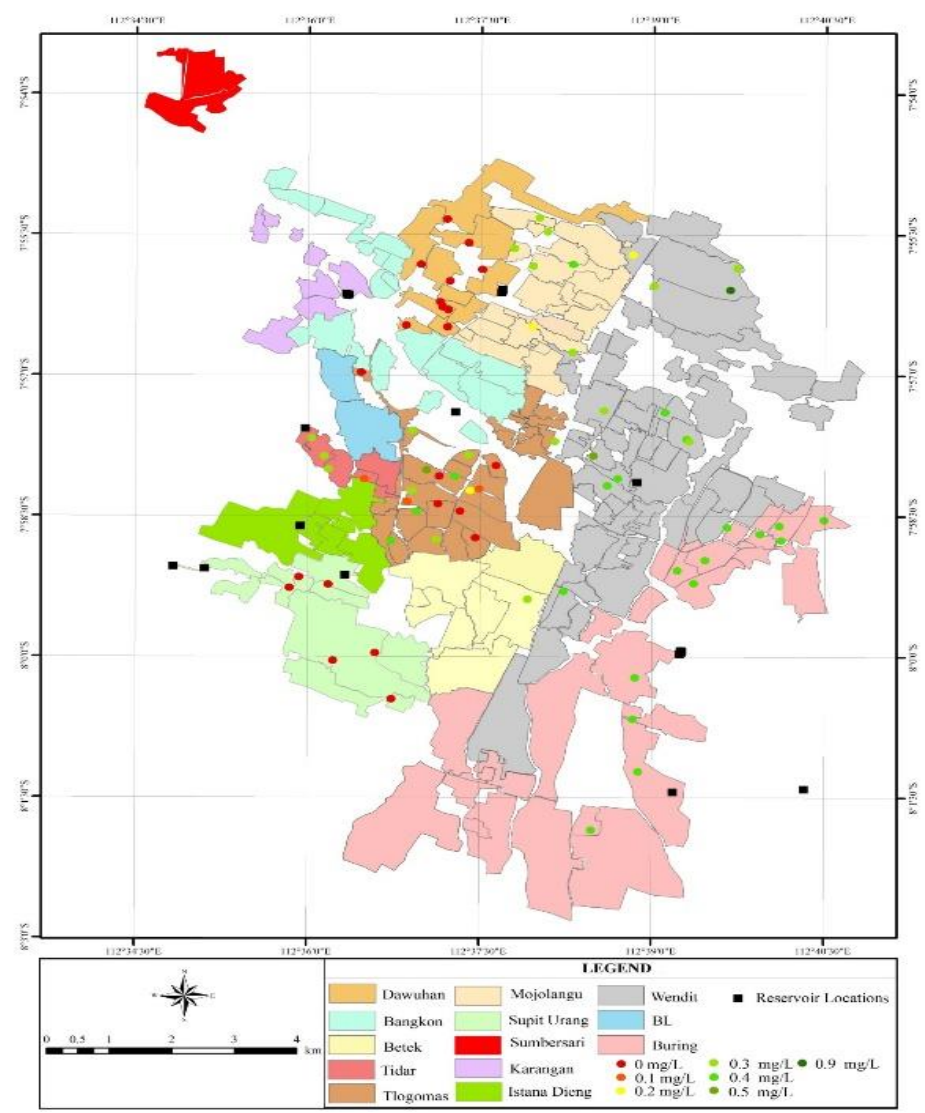

Fig. 2 - Map of residual chlorine at Malang City 


\subsection{Total Coliform}

Total coliforms are related very much to diarheea suffered by the customers. Based on the survey then diarheea is mostly caused by food rather than drinking water. Fig. 3 shows total coliform results. Yellow dots of Fig. 3 show sampling points with total coliform of 0 as required by 492/MENKES/PER/IV/2010. Red dots in two locations show sampling points of total coliform beyond standard. Results of Fig. 2 and Fig. 3 do not always coincide meaning although the residual chlorine is not available, but total coliforms are still 0. It is reasonable as raw water for Malang City is from spring or groundwater with very good quality. The total coliforms at the two locations may be caused by leakage, distribution pipe maintenance, or flooding.

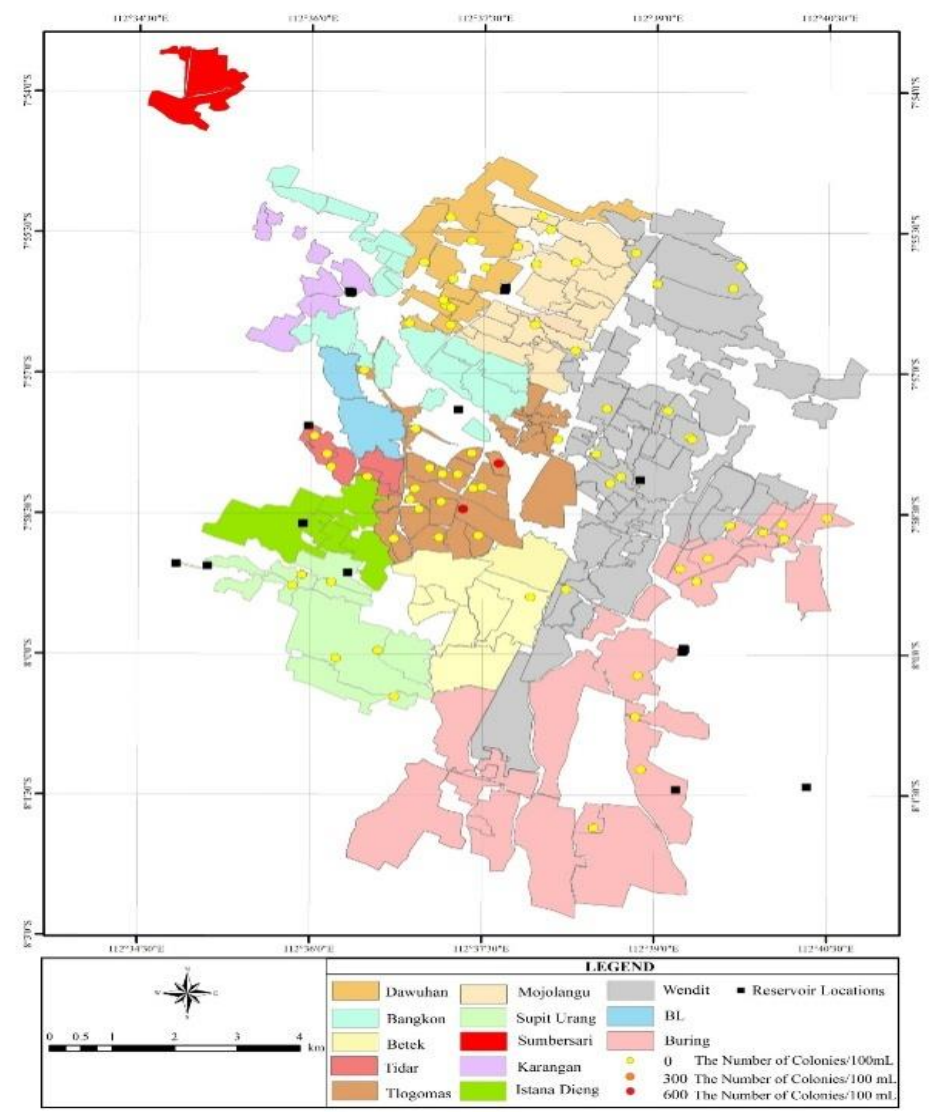

Fig. 3 - Map of total coliform at Malang City

\section{Pressure Head}

Obviously drinking water quality does not only comply with residual chlorine and total coliform standard as mentioned in Indonesia Standard, but water supply must also reach any PDAM customers with adequate pressure of minimum 1 bar for 24 hours. Minimum residual pressure at house connection is regulated for 0.5 bar. This is mainly due to poor pressure, especially at higher and farthest areas and certain customers which need to store lots of water for certain uses like hotels and industries.

Using SCADA at PDAM Office, the water pressure at distribution and customers are also known. Office and field results of pressure are compared and show good correlation. During the research, field pressure monitoring was conducted from 08.00 to 11.00 local time. Fig. 4 shows the results of pressure heads at Malang City. The figure shows that red dotted are places where water pressures are not adequate. There are 8 locations with pressure less than 0.5 bar. Blue color are locations with adequate pressures. Locations with low pressure are at Northern part of Malang City.

Further analysis was conducted based on the three field results of residual chlorine, total coliform content, and redual heads at the selected customers. Results were to be compared with the Indonesia Standards. Out of 85 DMA where samplings were conducted in February 2018, 58 samples complied with the Indonesia Standards. This was to say that $68 \%$ of the sampling results complied with the Standards. If there results were compared with the PDAM results from January 2017 until February 2018 then $85 \%$ of the sampling results complied with Indonesia Drinking Water Standards. 


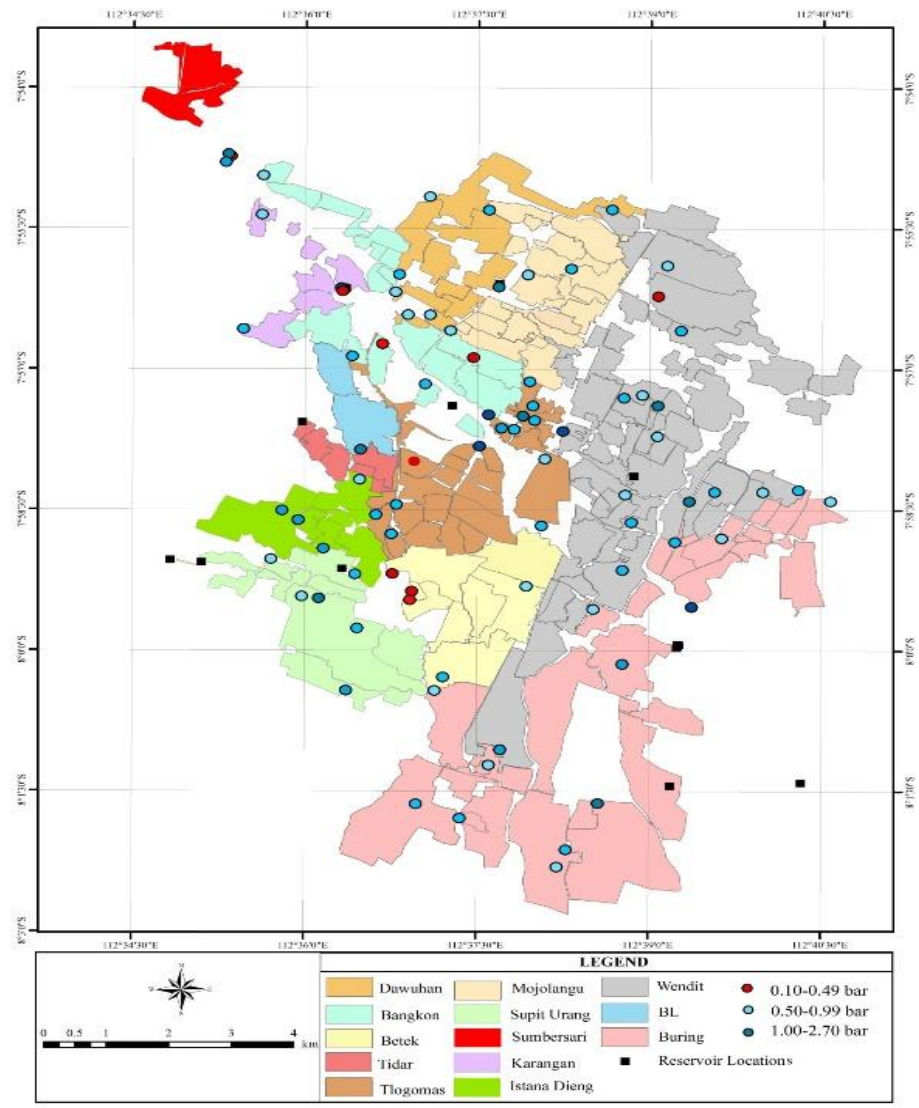

Fig. 4 - Pressure heads at distribution system at Malang City

\section{Conclusions}

Results shows that there are some sampling points at the Northern and Western part of Malang City which cannot comply with the Indonesia Drinking Water Standards regarding chlorine residual. This may be due to inadequate of chlorine dosing and due to dosing pumps failure at Dawuhan. There are 2 sampling points which cannot comply with the standard. Out of 85 DMA, 58 DMA are able to comply with the standard. Based on the PDAM sampling data from 2017 until February 2018, coverage of water supply of drinking water is $85 \%$ while this study concluded that $68 \%$ of the sampling points are drinking water.

\section{References}

1. Badan Pusat Statistik (BPS). (2016). Kota Malang Dalam Angka 2016. (Malang: Badan Pusat Statistik).

2. E. S. Soedjono and N. Arumsari. (2014). Healthy latrine development model to achieve MDGs target. AIP Conference: 4th International conference on mathematics and natural sciences (ICMNS 2012): Science for health, food, and sustainable energy. (Bandung, 8-9 November 2012).

3. B.M. Natalia, Mardiyono, and A. Said. (2014). Implementasi Program Zona Air Minum Prima (ZAMP) Untuk Memenuhi Kebutuhan Air Minum Masyarakat (Studi pada PDAM Kota Malang). Jurnal Administrasi Publik, 2(1), $11-15$.

4. J. R. C. Basset, G. H. Denney, J. Jeffrey, and Mendhom. (1994). Buku Ajar Vogel; Kimia Analisis Kuantitatif Anorganik. (Jakarta: EGC).

5. APHA. (2012). Standard Method for the Examination of Water and Wastewater 22 th ed. (Washington DC: American Public Health).

6. A. Masduqi, N. Endah, E. S. Soedjono, and W. Hadi. (2010). Structural equation modeling for assessing of the sustainability of rural water supply systems. IWA Publishing 2010 Water Science \& Technology: Water SupplyWSTWS 10.5 .

7. M. Ibroni. (2007). Tinjauan Pelaksanaan Chlorinasi Air Bersih dan Kaitannya dengan Sisa Chlor di PDAM Tirtanadi Medan Tahun 1997. e-journal FKM USU. 
8. R. Afrianita, S. P. Komala, and Y. Andriani. (2016). Kajian Kadar Sisa Klor di Jaringan Distribusi Penyediaan Air Minum Rayon 8 PDAM Kota Padang. Seminar Nasional Sains dan Teknologi Lingkungan II. (Padang). E-ISSN 2541-3880.

9. B. Syahputra. (2012). Analisis Sisa Chlor pada Jaringan Distribusi Air Minum PDAM Kota Semarang. Prosiding SNST ke-3. (UNISSULA Semarang). ISBN 978-602-99334-1-3.

10. E. Sofia and R. Riduan. (2017). Evaluasi Analisis Pola Sebaran Sisa Klor Bebas pada Jaringan Distribusi IPA Sungai Lulut PDAM Bandarmasih. Jukung Jurnal Teknik Lingkungan, 3(2), 10-24.

11. Menteri Kesehatan. (2010). Peraturan Menteri Kesehatan No. 492 Tahun 2010. Persyaratan Kualitas Air Minum. (Jakarta: Menteri Kesehatan).

12. Menteri Kesehatan. (2010). Peraturan Menteri Kesehatan No.736 Tahun 2010. Tata Laksana Pengawasan Kualitas Air Minum. (Jakarta: Menteri Kesehatan).

13. Menteri Pekerjaan Umum. (2013). Peraturan Menteri Pekerjaan Umum No. 13 Tahun 2013. Kebijakan dan Strategi Nasional Pengembangan Sistem Penyediaan Air Minum. (Jakarta: Menteri Pekerjaan Umum). 